\title{
THE EFFECT OF TEAM LEADERS ON MOTIVATION AND PERFORMANCE OF EMPLOYEES
}

\author{
Zeynep Derya DÜŞÜN ${ }^{1}$ and Beyhan DEMIR ${ }^{2}$ \\ ${ }^{1}$ Akbank Branch Manager. E-mail: ddusun@hotmail.com \\ ${ }^{2}$ Akbank Regıonal Dırector of the Southeastern Anatolia. Gaziantep, Turkey. E-mail: \\ Beyhan.Demir@akbank.com
}

\begin{abstract}
These days, due to the technological developments and increasing competition, business managers have an important role in reaching the business goals. In order to reach the goals, managers should have leadership qualities and value motivation and performance of employees. The purpose of this study is to determine the effects of leadership qualities of managers on motivation and performance of employees considering basic leadership qualities. Employees' motivation increase depending on the leadership qualities managers have. It has been confimed that there is a strong and directly proportional relationship between leadership or managers and performances of employees. The aim of this study is to understand how leadership qualities affect the motivation of employees.
\end{abstract}

Key Words: Leadership, Leader, Motivation, Performance

\section{Council for Innovative Research}

Peer Review Research Publishing System

\section{Journal: Journal of Social Sciences Research}

Vol. 9, No.1

jssreditor.cir@gmail.com 


\section{ISSN 2321-1091}

\section{INTRODUCTION}

Leadership and motivation have had an important place in human history. The history shows us that highly qualified leaders were very accomplished since they knew how to motivate their people (Serinkan, 2012: 149). Countries which have highly qualified leaders take other governments under their domination. All leaders with enthusiasm and great ability to manage her/his followers accomplish great success (Adair, 2013:2).

Leadership and motivation has become more important topics with the increase in competition all around the world. They are counted as one of the most important factors which affect the organizational success (Kaya, 2011: 15). Change and transformation phenomenon has been affecting the organizations since the beginning of 1900s by gaining speed (Ozzürk, 1998:2).

In today's world of competition, organizations should foresee the changes and therefore lay emphasis on the motivation of human resources which exist in their structure (Işık, 2014: 15). By motivating the labour power, organizations can attain their goals with a great success (Garih, 2013: 15-16).

The success of leaders and managers depend on the cooperation of employees towards the organizational goals (Serinkan, 2012: 150). In other words, motivation and performance are closely related. A good performance cannot be expected from an employee who is not motivated (Garih, 2013: 19). Employees display various behaviors each of which has different causes. The important thing for employees is to behave in accordance with the goals of the organization (http://www2.aku.edu.tr/ hozutku/sayfalar/tezsiz.htm).

Executives should focus on motivation and leadership topics in order to motivate employees to contribute to the business more (Kaya, 2011: 16). Employees or/and managers who are not satisfied with their jobs tend to face physical and psychological problems. Thus they may feel uncomfortable and detached about the company (Kaya, 2011: 16). The people who are unsatisfied with their work are in tendency to leave their job as soon as possible. Organizations which lose their qualified labor force encounter many difficulties and problems leading their failure (Kobjoll, 1996: 29).

This study focuses on the motivation and leadership which are very important topics for organizations. The concepts of leader and leadership were tried to be explained and information about the leadership types and features were given. Later, the concept of motivation and features and tools of motivation were explained. In the last part, the main focus of this study; "The Effect of Team Leader on the Performance and the Motivation of Employees" was discussed.

\section{LEADERSHIP AND LEADERSHIP TYPES}

Survival conditions of organizations have become more and more difficult due to technological developments and increasing competitive environment (http://pavlo vspartner.com/lidenlik-nedir-nasil-lider-olunur/). A leader who is able to use and direct both physical and human resources of a company can reach the company's goals more easily. (http://abdurrahmantufekci.blogcu.com/liderlik-kavrami/5962648). Although leadership is a crucial topic for organizations, it is not sufficient on its own. The process of methods of leaders should be managed in a very organized system (http://www.iktibas dergisi.com/liderlik-nedir-ve-lideri-lider-yapan-ozellik-nedir/) ).

Leadership and management are parts of a whole, which means they both necessitate each other to be efficient (Serinkan, 2012: 151). Leadership depends on processes among individuals, whereas management depends on organizational processes. Therefore, successful managers are as important as successful leaders. Organizational processes help and support leaders' business. (http://ekonomiturk.blogspot.com.tr/2010/03/liderlik-nedir.html)

\subsection{Leadership and Features of Leaders}

Leadership is the process of affecting and directing other people's activities in order to achieve the goals of certain individuals or groups under specific circumstances. Leader is a person who guides people to a certain purpose (Güney, 2007: 357). In other words, a leader is the one who is followed by individuals or group who/which are in pursuit of the same goals (Koçel, 2011: 569). A leader aims to achieve the business goals with the help of his/her followers (Serinkan, 2012: 151).

Leadership behaviors cover establishing interaction pattern to solve a common problem, indicating the way organization works and the relationship between the leader and the group members. Additionally, it necessitates building trust, sincerity and friendship in order to accomplish management goals (Şimşek, 2010: 197). Leadership is effective only when the leader contributes to the group to achieve success (Güney, 2007:357).

Individuals feel an obligation to belong to a group in order to achieve personal goals. A person is weaker and less brave when s/he is alone. Leadership is the sum of abilities and information to gather people around one certain goal and motivate them to reach that goal (Eren, 2001: 427). Businesses need leaders for several reasons, some of them are listed below (http://www.hrdergi.com/tr/dergi/nisan-2010/liderlik-fonksiyonu-insanlari-yonetmek-degil-insanlari-yonlendirerek-isiyonetmek-tir/1757.aspx) :

- Lack of planning in organizations

- Changing environment conditions

- Organizational climate

- Communication system 
- Participating in decisions

- Social supervision

- Internal dynamics of an organization like status and roles

- The relationship of organization members with other organizations

- Constant change

- Disharmony between the expectations and motivations of organization members

One of the most important reasons for the need of leadership is change. The fact that change is inevitable for organizations is a sufficient reason for leadership. As a matter of fact, leadership is mostly about making necessary arrangements in order for the organization to adapt the changes (Koçel, 2011:570).

Basic elements of leadership can be listed as below (http://isletmeiktisadi.istanbul.edu.tr/wpcontent/uploads/2013/04/Yonetim-50-2005-6.pdf) :

Settlement of Conflicts: Each person has a different idea on various topics. Sometimes there can be problems in expressing ideas which causes conflicts. Avoiding to solve these conflicts may cause lack of respect, even hostility among people (http://www.rec.org.tr/dyn files/32/185-catisma-cozme-hand-out-agu07.pdf).

Initiative: It involves leaders to focus on an activity or start a new business. Knowing the general frame of the tasks s/he's ordered by superiors, a leader acts on his/her decisions mostly. Sometimes s/he chooses not to take action, which also means s/he uses initiative (http://sekreterce.wordpress.com/2011/10/15/inisiyatif-alma/ ).

Being Interrogative: It is to ask detailed questions instead of accepting everything as it is. This characteristic provides people with truths and necessary data (Serinkan, 2012: 153).

Advocacy: It means to be a side of an idea, a vision or a belief. Every person has a different style to defend the things s/he believes. This is an indication of leadership style. Leaders have certain principles and views. They are people who have the sense of responsibility. In this aspect, leaders have the characteristic of advocacy since they have business philosophies to support. (http://www.yenimakale.com/taraf-olmak.html)

Decision Making: Carrying resources into execution is done by decision making. A leader may take all the decisions on his own or he can choose to have a team work dividing responsibilities among people. In this case, all the resources are used to make decisions and apply those decisions. (http://www.kigem.com/dogru-karar-alma-dersleri.html).

Criticism: There are several ways to measure the team members' way of problem solving. The key to this process is criticism. Using criticism forms a bas is for efficient work. Criticism, if done effectively, helps turn the resources into measurable consequences. This way, people would realize they can do better in most ways (http://www.cokbilgi.com/yazi/elestiri-nedir-tanimi-ve-ozellikleri/).

Not all managers have the qualities of leadership we mentioned. In other words, a manager does not mean a leader. However, businesses want to employ people who have the characteristics of a "lead manager" nowadays (http://www.ekonomist.com/genel/her-yonetici-bir-lider-midir.html). A manager is a person who has rights and authority, whereas a leader is the one who has power and skills. In short a a leader motivates and educates his subordinates and guides them in accordance with the principles and goals of the business (Koçel, 2011:572). A lead manager, on the other hand, is a person who is a; (Özgen, 2003:

- Organizer

- Problem solver

- Guider

- Coordinator

- Inspirer

- Mediator

- Participator

- Advisor

- Risk taker

Managers can be leaders, yet all leaders are not necessarily managers. A person may take the roles of both a leader and a manager. Being a manager requires to be able to handle the complications, while being a leader means to deal with the changes (Paksoy, 2002: 167).

The most important characteristic of leaders is to have influence on people towards change and transformation. The things that leaders are responsible for can be listed as below (Şimşek, 2010: 199):

1) Raising awareness

2) Helping people look beyond their interests

3) Helping people's work performance

4) Making people believe in the power of the change

5) Creating new organizational culture in accordance with the changes 
6) Aleader must improve himself

7) Balanced use of psychological, emotional, cognitive and physical developments.

8) In order to maintain leadership, a leader should have the qualities of cooperation, vision, values, courage, faith and resistance.

\subsection{Leadership Types}

There are formal and informal leadership types. Leaders are not necessarily authorized officially. Formal organizational structures are not a must to leaders (Şimşek, 2010: 198).Although leadership is an inborn skill, it can be improved with experience and perseverance (Güney, 2007:361).

Leadership types were briefly explained below (http:/www.pydem.com/Files/Pdfs/Egitimde-Toplam-KaliteYonetimi.pdf) :

1. Autocratical Leadership: Leaders have to give orders to people in order to help improve a philosophy or process or to give advices. Despite the fact that data collection, information dissemination and initial training are done by communicating subordinates, the last decision is always belongs to the leader. (http://www.em inipek.com/documents/Liderlik.pdf).

Autocratical leaders are the ones who were raised in a bureaucratic society. Since leaders and managers do not consider their subordinates' feelings and ideas, the level of job dissatisfaction is in maximum and the level of commitment to the organization is in minimum (http://enm.blogcu.com/liderlik-yonetici-yonetim-karar-verme4/9181441). This type of leadership must be applied in situations like organizational crisis, accidents and life-critical events (Serinkan, 2012: 156).

2. Coaching: In this type of leadership, leaders provide personal support as well as advices and guidance. In this system the main purpose is to train employees instead of controlling the business (http://www.academia.edu/8241570/Lider Tiplen ve Kocluk Modeli). These types of leaders are less stressed in organizational communications. These leaders encourage people by giving them incentives and advices (Koçel, 2011: 583).

3. Participative Leadership: This type of leadership includes low rate of guidance and high rate of support. Participative leaders create a motivational climate which allows employees to work in cooperation by using their knowledge and skills.

(http://blog.milliyet.com.tr/liderligin-dokuzuncu-penceresi--katılımcl- liderlik/14440).

4. Delegative Leadership: A delegative leader transfers his authority to make decisions to subordinates, yet remains responsible for their decisions. For this kind of leaders hip to take place, team members should be eager, selfconfident and skilled (Şimşek, 2010: 200):

5. Self-serving Leadership: Self-serving leaders raise and motivate themselves on their own.

(http://as osindex.com/article-search\&keyword=Kendi+Kendine+Liderlik).

6. Spiritual Leadership: This concept is developed to explain the inner motivation of people. The concept of spiritual leadership is mostly about vision, enthusiasm, sacrifice, love, organizing the work life and the. In this type of leadership employees are expected to be unselfish, satisfied with their job and to be at peace with other people (http://www.pegem.net/akademi/3-49381-Ruhsal-Liderlik-Uzerine-Teorik-Bir-Cozumleme.aspx).

7. Transformational Leadership: Transformational leaders motivate and guide employees to be leaders. These kinds of leaders take their employees very seriously regardless of their rank (http://www.pegem.net/akademi/3-822Donusumcu-Liderlik.aspx). Therefore employees look up to their leaders with admiration and trust (http://www.sosyalbilgiler.gen.tr/tag/donusumcu-liderlik-nedir).

Leadership types are not superior to one another in any way. A leader should be able to make the right decisions and execute them in necessary circumstances. In other words, there is not a leadership type which applies to every condition and every place. Leadership behaviors may differ depending on the business culture, management philosophies, condition of subordinates and environmental factors (Serinkan, 2012: 158).

\section{MOTIVATION}

Motivation means direction all the emotions towards a goal, creativity and action (Işık, 2014: 15). The underlying factors of motivation are hope, patience and morale. Edison made his discovery after 1000 experiments and considered 999 of them as teachings. Namely, motivation requires to be focused on the objective and not to quit no matter what happens on the way to the goal (https://minikkelebek.files.wordpress.com/2008/07/duygusal-zeka-ve-liderlik.pdf). Motivation involves an inner or an external stimulator which detemines the direction, power and priority of one's actions (Şahin, 2004: 524). 


\section{ISSN 2321-1091}

\subsection{Importance and Features of Motivation}

It is important for organizations or individuals to accomplish their goals. Hence, employees' satisfaction and motivation should be taken seriously (Kaya, 2011: 16). Employees should be trained for motivation by experts. This way training activities of businesses can be arranged in parallel with the goals (Bakan, 2011: 423). Both individuals and organizations benefit this situation (Adair, 2013: 16). Some of the demotivational factors were listed below (Güney, 2007: 293):

- $\quad$ Lack of self-confidence

- Hesitant attempts

- Poor outcomes

- Unsatisfying feedbacks

People who don't have self-confidence and are worried about the future cannot use their whole potential to focus on the work due to lack of motivation. Employees may feel responsible for the poor outcomes and think about quitting the job should they are accused by the managers (Garih, 2013: 34). Managers should always be in communication with the employees and be informed about the outcomes. Employees should be ready for the bad outcomes as well as the good ones so that they can do their part not to do the same mistakes (Serinkan, 2012: 160). Cons equently, managers should direct and motivate the personnel towards the business goals (Öztürk, 1998: 99).

\subsection{Motivational Tools}

Motivation can be made use of in order to increase the efficiency in organizations. The main purpose is to enhance the productivity of employees. To do that, incentive tools must be used (Eroğlu, 2001: 326).

It is very difficult to develop a motivational pattern for every individual, society or organization. However, there are motivational tools which can be divided in three parts (http://www.sosyalbilgiler.gen.tr/forum/yazili-evraklar-63/motivasyonnedir/?wap2):

1) Economical Tools

$>$ To produce high income

$>$ Wage rise accepted by employees and syndicates

$>$ Rate of premium

$>$ Reward system

2) Psycho-social Tools

> To be able to work independently

$>$ To have personal power and authority

$>$ To reach a social status

$>$ Job security and psychological assurance

> Suggestions and evaluation committees which considers the suggestions of employees

3) Organizational and Administrative Tools

$>$ Goal congruence: Organization and employees have mutual expectations.

$>$ Workforce planning: Detemination of work performances day by day. Providing training and advancement opportunities with the help of development plan.

$>$ Authority and responsibility equivalence: Managers should be able to transfer some of their authority and responsibility to subordinates.

$>$ Establishing an efficient communication system: A well established communication web in an organization motivates both employees and managers.

If we look at the recent studies about motivation, we can summarize the factors which increases work motivation (http://multiyasam.com/motivas yon-nedir-motivas yonu-artimanin-yolu/) :

1) Participation: Employees should have a right to comment on the reward system and regulations conducted in order to increase motivation.

2) Getting rid of the factors lessening motivation: If there is any factor hindering the people working on issues such as cooperation equipment, space, materials, instruction, support systems, it is useless to encourage the employee increase their performance.

3) Justice: If standards of performance do not bring a fair regulation among the employee, motivation -building measures do not work at all. 


\section{ISSN 2321-1091}

4) Strengthening: The employee should know that their performances are seen by the management. Some necessary applications that lead the employee to work to reach the wanted behaviour, to strengthen the results to learn well and supply feedback for the employee must be provided.

5) The significance of the award: It is necessary to understand how much engaging and important the served awards should be so that the encouraging measures can affect the performance in a positive way.

6) Aims: If the necessary things are explained well for the employees, an agreement is made and the necessary participation for the goals and behaviours is provided, encouraging measures make sense.

The employee will be satisfied with their jobs on the condition that the tools increasing motivation are given necessary importance to. There are consistent relations between job satisfaction and attendance and labour. (Serinkan, 2012: 163).

\subsection{Necessity of Leadership and Motivation}

Motivation has a big role to carry out their function for the organizations. For this, it is necessary to motivate the employee and groups (Marston, 2013:27). The fact that there is an emotional relationship between the working group members and the owners of the organization is a significant factor to increase the succeed (http://www.bm-institute.com/yazi/liderlik-vemotivas yon.html). As the inner motivations of the workers increase, the success of the organization will increase at the same ratio. For that reason, it is necessary to increase cooperation as well as welfare of the employees. (http://a ydinlarocagi.org/2013/08/is -guduleme-motivas yon-ve-is-tatmini/

One of the main aims of leaders is to explore the unbalance situations that the people whose needs are not met face and to find a solution for them. (http://www.iktibasdergisi.com/liderlik-nedir-ve-lideri-lider-yapan-ozellik-nedir/) On the other hand, this situation experienced by the person will affect behaviours, business efficiency and relationships of the person in a negative way. So, the management should provide that the purposes of the organization that actuates the energy and activity the employees have and provide that the employees are us eful in their jobs. (Adair, 2013:22).

The behaviours of individuals show their motivation. Accordingly, it is a must to observe behaviours of the employee and bring new models and applications to motivate them (Garih, 2013:44). Motivation is complementary for leadership. Active leadership affects the motivation of the employees in many conditions (Serinkan, 2012: 164). The owners of the organization need the leaders that comprehend the humanitarian sides of the organization and motivate and actuates people. An active leader is the person that is good at avoiding from the chaos and assessing the multiple perspectives (http://www.nlphaber.com/nlphaber-yazarlar-195/etkin-liderlik-sirlari.html). These abilities provide leaders with an opportunity to be able to develop positive relationships that help leaders reach their aims. (Şimşek, 2010: 201).

It is necessary to make a clearer plan to comply with the information age and to globalize. So, the abilities of the employees are really important. (Garih, 2013:47).

There is only one way to make people work, which is making them want to do it. (Işık, 2014: 69). It is really hard to motivate the employees that work in the area of scientific and technical and whose motivation is low. (Kobjoll, 1996: 29). For these reasons, the following factors are very important for making leadership: (http://www.sekreterdergisi.com.tr/index.php?option=com content\&task=view\&id=68) :
1. Vision
2. Trust
3. Participation

\section{Learning}

5. Variety

6. Creativeness

7. Honesty

\section{Community}

A successful organization means that there are enough personnel in the right time and right place. That the workers have high capacity ratios are good for the organization. Leaders should develop their relations with the talented people and should spend effort to make their missions successful (Garih, 2013: 95). It should not be expected that the motivation of the employees are high on the condition that the employee are not respected, the necessary education is not given to them and their successes are not known. It is possible that the organizations like those will go bankrupt because they cannot compete with others (Serinkan, 2012: 173).

A leader is the person that manages the differences. Management is the output of managers' inputs. Management is mainly an association of different factors in terms of goals (Şimşek, 2010: 13). The most important factor is human. Humans are different from each others in terms of feeling, acting, culture and values. (Bakan, 2011: 424).

The main mission of leaders is organize the valid labour sources, materials and tools, to make the workers' efforts compatible and to make them work in the most efficient way. At this point, the leader needs motivation. (Güney, 2007: 84).

As the human beings are different from each other, the factors motivating them are also different. The way they motivate on something is different because their needs are different (Koçel, 2011:619). As their needs are different and gradual, when one of them finishes, the other one may begin (Marston, 2013: 47). We can write the factors motivating people (http://blog.milliyet.com.tr/motivas yon--motivas yonun-tanimi--onemi--motivasyon-sureci-veteorileri/Blog/?BlogNo=277145):

* Personal Differences 
* Variety of needs

* Physical conditions

* Habits and attitudes of people

* Priority of needs according to the People

* Psychological differences

* Expectation differences

*Environment, social life

* Difference of values of people

Leaders should know those differences to motivate the individuals (http:/www.kigem.com/motivasyon-bilmecesi.html).

\section{The Importance of Motivation and Benefits Providing to the Management}

The place of motivation is great for the manager and the management because the success of the management relies on that acts work on the way of organizational aims and use their interest, ability and powers on this way (Adair, 2013: 73). It is very difficult to be successful for not motivated workers. The ability of power and ability to work, values, behaviours and needs of the members have an important effect on the success level of organization. (Garih, 2013: 17).

The manager today, is a person that must be both guiding and controlling others and making the Works of his/her asts easier, supporting them and inoculating love and loyalty to them (Serinkan, 2012: 159). There are some differences between the traditional and modern leadership. The ones adopting the traditional style give more importance to outside controls in the attitudes and behaviours of people. On the other hand, the modern managers believing the pers onal and social unity adopt the idea that the workers control themselves on their own and manage themselves on their own. (Genç, 1990: 19).

One of the main tools of the management is to increase the productivity of the members and accordingly of the organization. The organization should have the sound knowledge about human behaviour to motivate its members well.(Öztürk, 1998: 44).

Ensuring the motivation of the organization provides the following benefits to the organization and its members (Sarıkır, 2002: 81):

-Staff with motivation believes that they are different from others

-The activities are carried out according to the planned time and standards

-Propel enjoy working and think that they are respected

-People work more because they do what they love

-Mood of people will be good and the appropriate working environment will be provided.

When the personnel are motivated, serves equality products and work for making useful things. The motivated personnel do not have any limit for working, rather enjoy working. Relationships among the people develop thanks to motivation. Also, interest and engagement in job increases and stress and entrust does not happen (Işık, 2014: 34). Motivation of the organization is important for competing with others and the survival of the organization. Motivation is the guarantee of the organization. If there is no motivation, it is not the issue that there is success. (Garih, 2013: 20).

\section{Motivation of the Lead Manager and Staff}

There is a remarkable relationship between the chance of the manager's success and his motivation knowledge. A manager who has enough knowledge about how to motivate the employees in different circumstances, and who kn ows to use which means of stimulus while motivating them, has more chance of increasing organizational integration and working efficiency (http://www.yuksekhedef.com/hafiza/motguc.html). Employees do not like to work under extreme pressure; they do not like interferences everything about them, and to be given orders. Instead, the staff controlled on the sly will be motivated much more easily when working with the desire to work independently and use initiatives (Güney, 2007: 306)..

Motivating behaviours of leaders intended to increase the success of the staff are as follows (http://is metbarutcugil.wordpress.com/2014/04/18/baskalarini-motive-etmek/):

A leader can increase the motivation, and so, the success of his staff by giving them interesting awards.

A leader can improve the performance of the staff by clarifying business goals, providing guidance information to staff and by providing support and assistance.

A leader should give the necessary importance to the socio-psychological needs of the staff in order to eliminate monotony and fatigue resulted from routine work.

If a personnel feels he is in a different place in the organization, this will highly increase his efficiency. The leader is the person to make him feel in this way. Leadership style applied by managers in organizations is a tool itself that can inspire 
the members of the organization (Şimşek, 2010: 201). A manager should choose his leadership style considering such factors as his powers and features, the condition of the subordinates, organization type, effectiveness of the groups time, organizational goals and etc. so that he can better and easily understand himself, people and the groups he works with, and the organization and the environment in which he works. A manager will only be successful with this kind of approach throughout the motivational process (Güney, 2007:371).

Motivation differs in terms of authoritarian and Democratic leadership styles. The authority of an authoritarian leader depends on the power and strength. Therefore, the ones conforming to the order are awarded while the ones disobeying to the order are punished. The important thing is what the leader wants, not what an individual wants. On the other hand, a democratic leader tries to create a social environment in which people can easily do what they want. He helps individuals develop their own ideas. As the leader believes that people can make the best decisions for themselves, he thinks the right thing to do is to support and help them. (http://sosyolojisi.com/sosyoloji-makalelerinin-tamami/sosyoloji/sos yoloji-altbilim-dallari/mikro-sos yoloji/295-liderlik-cesitleri.html). Democratic leaders are better than autocratic leaders in terms of motivating their subordinates and making them more useful for the organization (Güney, 2007: 358).

\section{Tools Used by the Manager to motivate the Staff}

The main objective of management is to ensure the effective and efficient use of available resources. The basis of management activities is the human factor. The manager is a key factor for participating one's physical, mental and psychological power in the production process (Koçel, 2011: 59). The manager needs to motivate the staff so that they can dynamically use all of their efforts for the production. The main task of the manager is to create an effectively working organization (Işık, 2014: 16). There is a close close relationship between the chance of the manager's success and his motivation knowledge. A manager who has enough knowledge about how to motivate the employees in different circumstances, and who knows to use which means of stimulus while motivating them, has more chance of increasing organizational integration and working efficiency (Garih, 2013:17).

Clorana Francis - a philosopher- says the followings about the motivation (Karaali, 2005: 92) :

"You can buy some of the time of a person, you can make a person actually present in a certain place, you can even buy hourly or daily basis - an individual's physical activities that require a certain degree of skill. However, you cannot buy the initiatives, loyalty or de votion of anybody. These are not obtainable, but earnable."

As the features stated above cannot be bought, but earned, today's managers should have a personality that ease the work of directors and that can instil love and commitment by supporting them (Genç, 1990: 71)..

Managers use the following motivational tools in accordance with the social, cultural and psychological features of the staff (Adair, 2013: 219-220):

- Appreciation

- Freedom at work

- Authorization and Responsibility

- Caring for Organizational Values

- Self-confidence

- Sense of Belonging

- Unity of Goals

- Feedback

- Agreeing with the Decisions

- Honesty

- Fairness

- Value and Status

- Improvement and Success

- Suggestion System

- Psychological Assurance

Managers aim at pleasing the staff by using the following motivational tools (http://www.kigem .com/yonetim-araci-olarakmotivasyon.html):

- Ensuring the Participation in Social Activities

- In-service Training

- Remembering the Staff on Special Occasions

- Unionization 
The most powerful factor that pushes employees to work is to get a wage in order to sustain his and his family's life. The staff will try to perform what superordinates require them to do, because their great fear is to lose their job that is the $m$ ain source of income. Therefore, economical motivational tools are also important. They are (http://www.ikpaylas im.com/ucretve-sosyal-iliskilerin-calisan-motivas yonuna-etkisi/):

-Salary

-Participation in the Profits

-Economical Rewards

Physical environment is the entire of the environment where the staff works and interacts with each other. Working environment should be sanitary, clean, comfortable and aesthetic. Working environments may affect employees positively or negatively. These are (Karaali, 2005: 102):

- Physical Working Conditions

- Tools and Materials

- Business Planning

- Job Rotation

- Job Enlargement

- Job Enrichment

- Communication

- Flexible-time Practice

\section{CONCLUSION}

Motivation is the process of encouraging the staff to work and making them believe that their individual needs will be pleased if they effectively work in the organization. People work in the organizations for some specific purposes. These purposes can be production or service. In return for the service that employees provide, they get something such as money, food, clothes and etc. Thus, the staff is motivated to work according to the organization's goals. Also, in this way, they are directed towards a certain direction.

Such elements as environmental factors, habits and social environment affect motivation as well as physiological and psychological factor. When the needs and demands (psychological or material) of the staff are not fulfilled some problems occur within the staff. Therefore, the employees become sad because of these problems, and this also affects his performance. An individual's will to work increases because of the environment that the administration prepared, supplied physiological and psycho-social tools, and the demands and needs of the individuals. Thus, these external tools, which help individuals realize their goals, enable them to adopt the goals of the organization they work and to concentrate their efforts on this way.

As everyone is different from each other, the elements to motivate them are also different. Motivation methods are different due to the difference of people's needs or meeting the same need in a different way. For example, some people states that the reason why they work more in order to earn more money is to buy better and enough food, and better clothes while some others may want to get respect and social status. Different expectations also lead to emerging the motives in a different way, and this shows us how complicated the motivation is.

As the needs of individuals are different and gradual, when one is fulfilled another one comes up. This is also complex because it requires continuity and diversity while motivating the staff. A motivating tool may affect an individual negativel y after a while.

Managers use some socio-psychological motivational tools in order to motivate the staff such as aappreciation, freedom at work, authorization and responsibility, caring for organizational values, self-confidence, sense of belonging, and etc. Thanks to these motivational tools, which managers use or may use, employees adopt their work and they are engaged in activities for greater effectiveness and efficiency.

As a result, not only the objectives of the organization but also the goals of the employees are realized. Positive atmosphere resulting from the compliance between the administration and the staff will absolutely affect the organization with a positive feedback.

\section{REFERENCES:}

1. Adair, J. (2013), Etkili Motivasyon, Çev: Salih Uyan, İstanbul: Babıali Kültür Yayıncılığı, 4. Baskı

2. Bakan, İ. (2011), Çağdaş Yönetim Yaklaşımları İlkeler, Kavramlar ve Yaklaşımlar, İstanbul: Beta Basım Yayım Dağıtım A.Ş. , 2. Baskı

3. Eroğlu, F. (2004), Davranış Bilimleri, İstanbul: Beta Basım A.Ş, 6. Baskı

4. Garih, Ü. (2013), İş Hayatında Motivasyon, İstanbul: Hayat Yayın Grubu, 1. Baskı 


\section{ISSN 2321-1091}

5. Genç, N. (1990), Kamu ve Özel Sektör Yöneticilerinin "Astların Motivasyonu” Açısından Değerlendirilmesi, Atatürk Üniversitesi S.B.E. Doktora Tezi

6. Güney, S. (2007), Yönetim ve Organizasyon, Ankara: Nobel Yayın Dağıtım, 2. Baskı

7. Işık, Y. (2014), Motivasyon Mucizesi, İstanbul: Sis Yayıncılık ve Dağıtım Ltd. Şti, 1. Baskı

8. Karaali, A. (2005), Personelin Motivasyonu Üzerinde Lider Yöneticinin Rolü, A.Ü. Sosyal Bilimler Enstitüsü İnsan Kaynakları Yönetimi ve Kariyer Danışmanlığı Ana Bilim Dalı, Dönem Projesi

9. Kaya, Y. (2011), Motivasyon Stratejileri, İstanbul: Gerekli Kitap, 1. Baskı

10. Kobjoll, K. (1996), Motivasyon, Çev: Veli Karaöz, İstanbul: Evrim Yayınevi ve Tic. Ltd. Şti, 1. Baskı

11. Koçel, T. (2011), İşletme Yöneticiliği, İstanbul: Beta Basım A.Ş, 13. Baskı

12. Közleme, O. (2013), Liderlik, Siyasal Otorite ve Tipleri ve Karizma, Toplum Bilimleri Dergisi, Sayı.7(13)

13. Marston, R.S. (2013), Günde Bir Doz Motivasyon, İstanbul: Koton Kitap Yayıncılık Ltd. Şti, 1. Baskı

14. Özgen, E. (2003), İletişim ve Liderlik, Gazi Üniversitesi, İletişim Dergisi, Sayı: 18

15. Özsalmanlı, Y.A. (2005), Türkiye'de Kamu Yönetiminde Liderlik ve Lider Yöneticilik, Manas Üniversitesi, Sosyal Bilimler Dergisi, Sayı:13

16. Öztürk, A. (1998), Küreselleşen Dünya'da Yöneticilik, Adana: Nobel Kitapevi, 1. Baskı

17. Paksoy, M. (2002), Çalısma Ortamında İnsan ve Toplam Kalite Yönetimi, İstanbul, Çantay

18. Sarıkır, F. (2002), Takım Liderliği ve Bunun Takım Motivasyonu Üzerine Etkileri, Atatürk Üniversitesi S.B.E. Yüksek Lisans Tezi

19. Serinkan, C. (2012), Liderlik ve Motivasyon Geleneksel ve Güncel Yaklaşımlar, Ankara: Nobel Akademik Yayıncılık, 3. Baskı

20. Şahin, A. (2004), Yönetim Kurumları ve Motivasyon İlişkisi, Selçuk Üniversitesi, Sosyal Bilimler Enstitüsü Dergisi, Sayl:11

21. Şimşek, M.Ş. (2010), Yönetim ve Organizasyon, Konya: Eğitim Akademi Yayınları, 12. Basım

22. Ülgen, H. Ve Mi zre, S.K. (2010), İşletmelerde Stratejik Yönetim, İstanbul: Beta Basım A.Ş., 5. Baskı

23. http://abdurrahmantufekci.blogcu.com/liderlik-kavrami/5962648

24. http://www.academia.edu/8241570/Lider Tipleri ve Kocluk Modeli

25. http://www2.aku.edu.tr/ hozutku/sayfalar/tezsiz.htm

26. http://asosindex.com/article-search\&keyword=Kendi+Kendine+Liderlik

27. http://aydinlarocagi.org/2013/08/is-guduleme-motivas yon-ve-is-tatmini/

28. http://blog.milliyet.com .tr/motivas yon--motivas yonun-tanimi--onemi--motivas yon-sureci-veteorileri/Blog/?BlogNo=277145

29. http://blog.milliyet.com .tr/liderligin-dokuzuncu-penceresi--katılımcl- liderlik/14440

30. http://www.bm-ins titute.com/yazi/liderlik-ve-motivasyon.html

31. http://www.cokbilgi.com/yazi/elestiri-nedir-tanimi-ve-ozellikleri/

32. http://www.ekonom ist.com/genel/her-yonetici-bir-lider-midir.html

33. http://ekonomiturk.blogspot.com .tr/2010/03/liderlik-nedir.html

34. http://www.eminipek.com/documents/Liderlik.pdf

35. http://enm .blogcu.com/liderlik-yonetici-yonetim-karar-verme-4/9181441

36. http://www.hrdergi.com/tr/dergi/nisan-2010/liderlik-fonksiyonu-insanlari-yonetmek-degil-insanlari-yonlendirerek-isiyonetmek-tir/1757.aspx

37. http://www.ikpaylasim.com/ucret-ve-sosyal-iliskilerin-calisan-motivas yonuna etkisi/

38. http://www.iktibas dergisi.com/liderlik-nedir-ve-lideri-lider-yapan-ozellik-nedir/

39. http://isletmeiktisadi.istanbul.edu.tr/wp-content/uploads/2013/04/Yonetim-50-2005-6.pdf

40. http://ismetbarutcugil.wordpress.com/2014/04/18/baskalarini-motive-etmek/

41. http://www.kigem.com/dogru-karar-alma-dersleri.html 
42. http://www.kigem.com/motivas yon-bilmecesi.html

43. http://www.kigem.com/yonetim-araci-olarak-motivas yon.html

44. https://minikkelebek.files.wordpress.com/2008/07/duygusal-zeka-ve-liderlik.pdf

45. http://multiyas am .com/motivas yon-nedir-motivas yonu-artimanin-yolu/

46. http://www.nlphaber.com/nlphaber-yazarlar-195/etkin-liderlik-sirlari.html

47. http://pavlovspartner.com/liderlik-nedir-nasil-lider-olunur/

48. http://www.pegem.net/akademi/3-822-Donusumcu-Liderlik.aspx

49. http://ww.pegem.net/akademi/3-49381-Ruhsal-Liderlik-Uzerine-Teorik-Bir-Cozumleme.aspx

50. http://www.pydem.com/Files/Pdfs/Egitimde-Toplam-Kalite-Yonetimi.pdf

51. http://www.rec.org.tr/dyn files/32/185-catisma-cozme-hand-out-agu07.pdf

52. http://sekreterce.wordpress.com/2011/10/15/inisiyatif-alma/

53. http://www.sekreterdergisi.com.tr/index.php?option=com content\&task=view\&id=68

54. http://www.sosyalbilgiler.gen.tr/forum/yazili-evraklar-63/motivasyon-nedir/?wap2

55. http://www.sosyalbilgiler.gen.tr/tag/donusumcu-liderlik-nedir/

56. http://sos yolojisi.com/sos yoloji-makalelerinin-tamami/sos yoloji/sos yoloji-alt-bilim-dallan/mikro-sos yoloii/295-liderlikcesitleri.html

57. http://www.yenimakale.com/taraf-olmak.html

58. http://www.yuksekhedef.com/hafiza/motguc.html 